\title{
Monitoring of water quality and hydrodynamic model of pollution load in Dniepr transboundary river
}

\author{
V. Korneev \\ Central Research Institute on Complex Use of Water Resources \\ (CRICUWR) Minsk, Republic of Belarus
}

\begin{abstract}
This publication has a common approach to development of the monitoring and assessment of the river basin, and also estimation of anthropogenic environment effect in case of accidental situation. With the purpose of preventing ecological hazard and development of effective administrative solutions with help of the mathematical model of river basin incl. prognosis hydrodynamic model of transboundary pollution's transfer. The modern level of development of science allows us to create information system of monitoring and assessment of the Dniepr river basin. The information system are created on the base of GIStechnologies and includes data of National Systems of Monitoring since 1989 on about 50 - quality and quantity water parameters. These information systems also include assessment of water quality with use statistical models and prognosis hydrodynamic model. The main attention in this article is given to the description of the system of monitoring and hydrodynamic model for the prognosis of water quality, especially in case of emergency situations.
\end{abstract}

\section{Introduction}

The Dniepr river is one of the main transboundary rivers of the Europe. Catchment area of the river basin is disposed on the territory of Russia, Belarus, Ukraine. The river plays the main role in economic activity of the people, which one live in the river basin. The main source of surface waters pollution in the Dnepr river basin is an intensive industrial and agricultural production. The point 


\section{Environmental Health Risk}

sources of pollution are municipal waste waters from storm water sewage, industrial and agricultural companies.

The most crucial problems for the basin of the Dniepr river are as follows:

- unsatisfactory technology of water cleaning in Waste Water Treatment Plants (WWTPs) and potential hazard of accidental organic substances and biogenic pollution load;

- accidental pollution due to saturation of the region with industrial enterprises, oil and petroleum products pipelines;

- pollution with organic substances, originating from point and diffuse sources as a result of active agricultural activities;

- pollution with biogenic substances and eutrofication;

Developing of the System of Complex Assessment for the Dniepr river basin are very important tacking into account large significance of the Dniepr-river monitoring system for the effective forecasting and solutions of all ecological problem in the river basin.

\section{Monitoring of water quality in the Dniepr River Basin}

Department on Hydrometeorology of the Ministry of Natural Resources and Environmental Protection of the Republic of Belarus make measuring procedure of the quantitative and qualitative parameters of water of the Dniepr river and its tributaries based on the set of hydrological and hydrochemical observations. The hydrological points make standard measuring technique of hydrological regime (daily observations of water level and water discharge in applicable points). The samples on hydrochemical points are made 12 times per year for the Dniepr and its main tributaries (Pripiat, Soj, Berezina, Svisloch) and 7 times per year for other tributaries. The measured parameters list contains about 50 of the names. In the Dniepr river basin 79 hydrological and hydrochemical points of observations are situated (see fig.1).

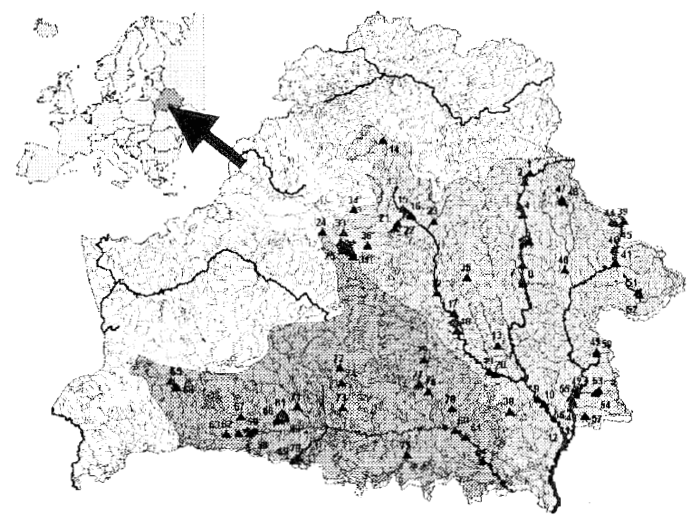

Figure 1. Monitoring set in the Dniepr river basin in the territory of the Republic of Belarus 


\section{Hydrodynamic model of pollution load in Dniepr transboundary river}

Hydrodynamic model of pollution load in Dnepr river are based on the common decision of the equations of movement of water and equation of the movement of a pollution.

\subsection{Hydrodynamic model of the movement of water in a river basins}

Hydrodynamic model of the qualitative characteristics of a water source (water levels, discharges, average velocities and velocity distribution in each cross section of the river) are based on the Sean-Venan - generalized equations.

It is necessary to find $z(x, t)$ (water level) and $Q(x, t)$ (water discharge) from the hyperbolic system of equations [2],[3].

$\mathrm{B}_{0} \frac{\partial \mathrm{z}}{\partial \mathrm{t}}+\frac{\partial \mathrm{Q}}{\partial \mathrm{x}}=\mathrm{q}$

$\frac{\partial Q}{\partial t}+2 v \frac{\partial Q}{\partial x}+\left(c^{2}-v^{2}\right) B_{1} \frac{\partial z}{\partial x}=\Phi$

which satisfies to following conditions:

$$
\begin{array}{lll}
\text { - initial } & \mathrm{Q}(\mathrm{x}, \mathrm{t})=\mathrm{Q}_{0}(\mathrm{x}) ; & \mathrm{z}(\mathrm{x}, \mathrm{t})=\mathrm{z}_{0}(\mathrm{x}) \\
\text { - boundary } & \mathrm{Q}(0, \mathrm{t})=\varphi(\mathrm{t}) ; & \mathrm{Q}(\mathrm{L}, \mathrm{z})=\psi(\mathrm{z})
\end{array}
$$

where : $\Phi=\left[B_{1} I_{0}+\left.\left(\frac{\partial \omega}{\partial x}\right)\right|_{h=\text { const }}\right] v^{2}-g \omega \frac{Q|Q|}{K^{2}} ; \quad v=\frac{Q}{\omega} ; \quad c=\sqrt{g \frac{\omega}{B_{1}}}$

Q- water discharge,

$B$ - width of transitional part of cross-section,

$B_{0}$ - width of common cross-section (including transit and not transit zones);

$\omega-$ area of cross section;

$c=\sqrt{g \omega / B_{0}}$;

$V$ - kinematics coefficient of viscosity;

$\mathrm{q}$ - inflow discharge ;

$\mathrm{K}$ - conveyance;

$\mathrm{I}_{0}$ - bottom gradient

One of the main parameters of the model is conveyance $K=\omega C_{R} \sqrt{R}$.

Calculation $\mathrm{K}$ and $\mathrm{C}_{\mathrm{R}}$ based on hypothesis about equivalence of replacement of the real flow on superposition of two flat rectangular flows: vertical with depth $\mathrm{H}$ and horizontal with width $\mathrm{B}$. 
36 Environmental Health Risk

$$
\left\{\begin{array}{l}
C_{H} \sqrt{H I}=\frac{1}{\omega} \int_{0}^{B_{0}} \int_{0}^{h(y)} u_{h}(h, y) d h d y \\
C_{B} \sqrt{B I}=\frac{1}{\omega} \int_{0}^{H_{H A X x}} \int_{0}^{y(h)} u_{y}(y, h) d y d h \\
\frac{1}{H}+\frac{1}{B}=\frac{1}{R}
\end{array}\right.
$$

where

$\omega$ - area of cross-section,

$\mathrm{Uh}(\mathrm{h}, \mathrm{y})$ - velocities of vertical of flows,

$\mathrm{Uy}(\mathrm{y}, \mathrm{h})$ - velocities of horizontal flows.

$\mathrm{H}$ - depth of the equivalent hypothetically rectangular flow;

$\mathrm{B}$ - width of the equivalent hypothetically rectangular flow;

$\mathrm{C}_{\mathrm{H}}, \mathrm{C}_{\mathrm{B}}$ - Shezi-coefficients for the equivalent hypothetically rectangular flow;

$\mathrm{R}$ - hydraulic radius.

The solution of nonlinear system (5) - B, H - allow to calculate Shezicoefficients for the equivalent hypothetically rectangular flow $\mathrm{C}_{\mathrm{H}}, \mathrm{C}_{\mathrm{B}}$, Shezicoefficients for real cross section of flow $C_{R}$, longitudinal average velocity $\mathrm{V}=\mathrm{C}_{\mathrm{R}} \sqrt{\boldsymbol{A}}$ and longitudinal velocity distribution in the supposition of the logarithmic law of distribution of a velocity on a vertical.

After solution of the systems nonlinear equation (5) and receiving of all coefficients which included in system of equations (1)-(2) the system (1)-(2) are solve by the method of finite difference [2],[3],[4] tacking into account initial and boundaries data (3),(4).

The algorithm of identification of parameters of the model is stipulated tacking into account observed data.

These mathematical models have passed successful approbation at calculation of various water regimes of the rivers (Pripiat, Irtysh, Dniepr, Aracks, Western Dvina etc.) [1],[5].

\subsection{Hydrodynamic model of the movement of pollution in a river basin}

Hydrodynamic model of the movement of pollution in a river are based on the equations of turbulent diffusion [2], [3].

For the dissolved pollution:

$\frac{\partial(\omega C)}{\partial t}+\frac{\partial(\omega V C)}{\partial x}=\frac{\partial}{\partial x}\left(\omega D \frac{\partial C}{\partial x}\right)+\omega f$

which satisfies to following conditions:

- initial $C\left(x, t_{0}\right)=\varphi(x)$ 


$$
\text { - boundary } C(0, t)=\psi(t)
$$

where :

C - concentration of pollutant ( $\mathrm{mg} / \mathrm{l})$;

$\omega$ - area of cross section;

$\mathrm{V}$ - average longitudinal velocity;

D - longitudinal dispersion coefficient.

For the surface pollution (for example - surface part of petroleum) [6]:

$$
\frac{\partial C_{x}}{\partial t}+\frac{\partial}{\partial x}\left(U_{x} C_{x}\right)=\frac{\partial}{\partial x}\left(D_{x} \frac{\partial C_{x}}{\partial x}\right)-C_{x} S_{1}-F+P
$$

which satisfies to following conditions :

$$
\begin{aligned}
& \text { - initial } C_{x}\left(x, t_{0}\right)=\varphi(x) \\
& \text { - } \quad \text { boundary } C_{x}(0, t)=\psi(t)
\end{aligned}
$$

where:

$\mathrm{U}_{\mathrm{x}}$ - average surface velocity

$\mathrm{C}_{\mathrm{X}}$ - average thickness of petroleum layer;

$\mathrm{D}_{\mathrm{x}}$ - coefficient of longitudinal dispersion;

$\mathrm{S}_{1}$ - coefficient which is taking into account destruction of petroleum;

$\mathrm{F}$ - parameter which is taking into account evaporation of petroleum;

$\mathrm{P}$ - capacity of sources of receipt of petroleum in water object

The equations (6),(9) with initial and boundary condition (7),(8) and (10),(11) accordingly are solve by the method of finite difference [2],[3],[4].

Comparison of the results of mathematical model with experimental data and example of modeling are presented in figures 2,3 .

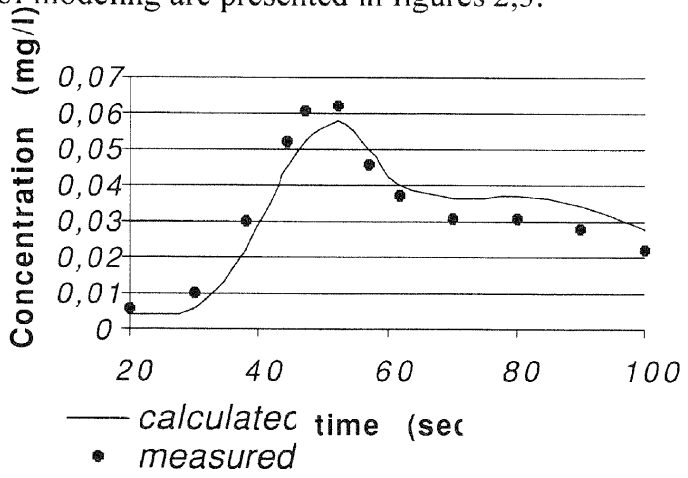

Figure 2. Results of mathematical modeling of dissolved pollution (ammonium nitrogen) moving in Oressa river (the second order tributary of Dniepr) $385 \mathrm{~m}$ after the location of an accident. 
38 Environmental Health Risk

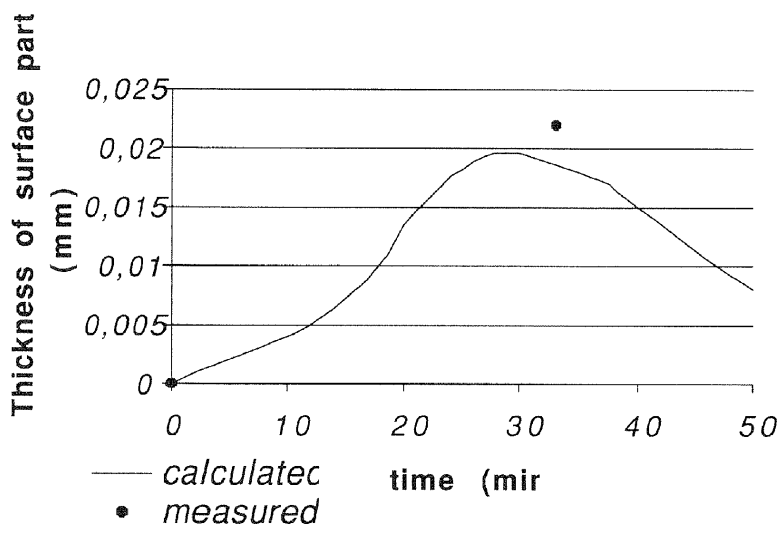

Figure 3. Results of mathematical modeling of petroleum moving in Svisloch river (the second order tributaries of Dniepr) after 570 $m$ after the location of an accident.

For the purposes of a pollution loads assessment and prognosis of a pollution transboundary transfer in Dniepr river the hydrodynamic model was developed.

The hydrodynamic model of the Dniepr river are developed also with using of GIS- techniques and base on the data of the National Systems of Monitoring too. This model allow to carry out the following functions:

- to calculate various characteristics of pollutant in the river basin systems (concentration of pollutant, when and in which sites of river excess of Maximum Admissible Concentration-MAC, time of their receipt for each site and duration of their presence on given site;

- to determine of pollutant total discharge for the probable point source located in the river basin;

- to calculate summary pollution loads and transboundary discharge of pollutant.

Initial data for the hydrodynamic model includes the next information:

a) For the modeling of qualitative characteristics of water (water levels, discharges, average velocities and velocity distribution in each cross section of the river etc.)

- $\quad\left(x_{j}, y_{j}\right)_{i}$ coordinates for each cross sections of the river incl. transit and not transit (flood plain) zone and local grain coefficients for each sites of the perimeter of cross section;

- hydrological data which includes daily observed values of water level $\mathrm{Z}\left(\mathrm{x}_{\mathrm{n}}, \mathrm{t}\right)$ and water discharges $\mathrm{Q}\left(\mathrm{x}_{\mathrm{n}}, \mathrm{t}\right)$ in the base points of observation which situated in the Dnepr and its tributaries.

b) For the water pollution loads and their transboundary transfer modeling

- summary discharges of pollutant in case of accident and approximately time interval of the pollutant loads into the river, time and place of accident or: 
- graph of pollutant loads which measured in the river in point which situated below of place of accident;

- places of main point sources and their averages discharges of waste waters and average pollution loads.

Example of a results of hydrodynamics model of a movement of petroleum after 4 day after accident are present on the fig. 4 (surface and dissolved part). For next step on time we have a new figure.

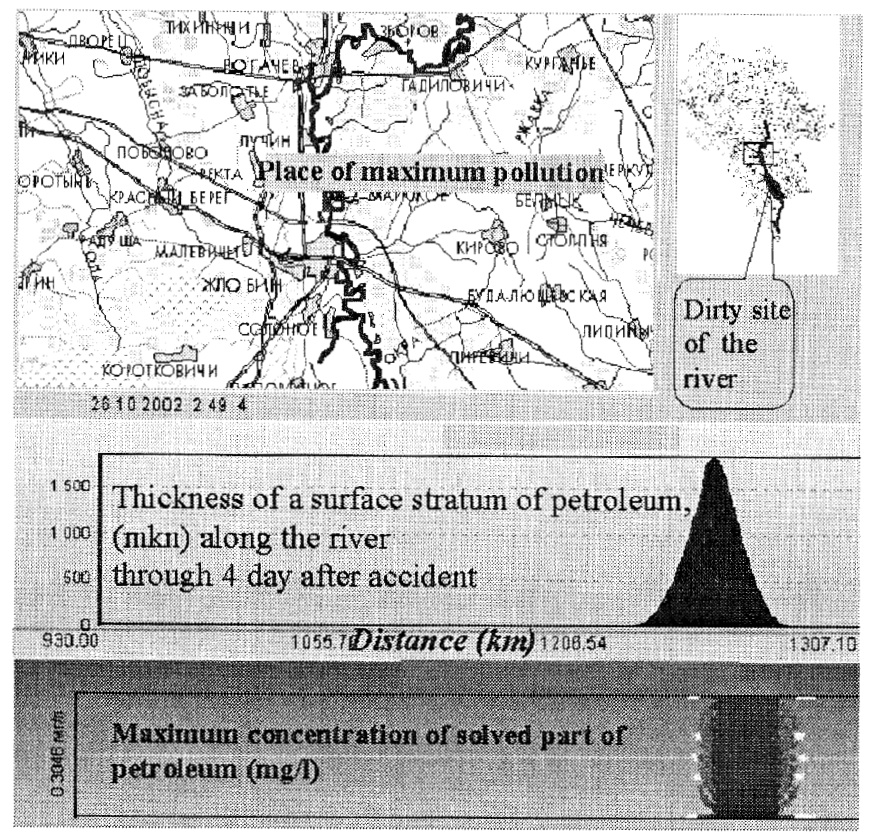

Figure 4. Example of operation of the hydrodynamic prognosis model for the Dniepr river

\section{References}

[1] Chekan, G., Stankevish, A., Korneev V., System of monitoring and assessment of the transboundary river basin in Belarus, International Conference on Hydrological Challenges in Transboundary Water Resources Management, Koblenz, Germany, 25-27 September, 2001, pp.153-158.

[2] Cunge, J.A., Holly F.,M., Verwey, A., Practical Aspects of Computational River Hydraulics, Pitman Advanced Publishing Program, London, 1980, pp.17-23. 
40 Environmental Health Risk

[3] Rogunovich, V., Autoimmunization of a mathematical modeling of flow and substance transport in the water-stream systems, St.-Petersburg, 1989 (Russian), p 263.

[4] Fletcher, C.A., Comparison of the Finite Element and Finite Difference Methods for Computational Fluid Dynamics, Finite Elem. Flow. Anal. Proc. $4^{\text {th }}$ Int. Symp. Finite Elem. Meth. Flow. Probl., Tokyo, July 26-29, 1982, pp. $1003-1010$.

[5] Korneev, V., Rogunovich, V., Stanckevich, A., Water regime of the river Pripiat and its runs at incomplete realization of the design of guard of basin from deluging. International Conference "Modern problems of study, usage and protection of natural recourses of Polesje-region", Minsk (Russian). p. 120 .

[6] Musoian, S.G, Shmidt, E.L., Distribution of petroleum in the river in case of accident (on example of Moscow region). Journal. Guard from corrosion and environmental protection, Vol. No 3, pp.15-16, Moscow, (Russian), 1997. 